\title{
Part-time Jobs: Opportunity or Obstacle? Case of the Moravian-Silesian Region
}

\author{
Šárka ČEMERKOVÁ, Jarmila ŠEBESTOVÁ, Roman ŠPERKA
}

\author{
Silesian University in Opava, School of Business Administration in Karviná, Department of Business Economics \\ and Management, Univerzitní náměstí 1934/3, Karviná, Czech Republic \\ cemerkova@opf.slu.cz, sebestova@opf.slu.cz, sperka@opf.slu.cz
}

\begin{abstract}
Background and Purpose: Part-time employment could be seen as a modern form of employment or a type of innovative organizational change. The average share of part-time jobs in the Czech Republic in the observed period of 2004-2016 was $3.9 \%$ according to the OECD, in comparison to the average OECD value of $16.6 \%$. The main question to arise was, are there any regional differences? The presented conclusions are based on a regional study in the Moravian-Silesian Region (MSR) in the Czech Republic where the median value of part- time jobs is $10 \%$. The main goal is to evaluate the regional level of part-time job offers and identify the main opportunities and obstacles which cause the low number of these job positions.

Design/Methodology/Approach: The paper is based on a quantitative study using a questionnaire-based survey, comprising 215 respondents - owners of small and medium-sized enterprises (SMEs) in the Moravian-Silesian Region in the Czech Republic. The survey consists of 16 questions in three main areas: (i) Entrepreneurial motivation (1 item), (ii) External factors - Labour market problems (4 items), and (iii) Internal factors. Secondary information such as the results of earlier studies and regional government websites were used for data results comparison. All variables are compared in the context of the branch of business, number of employees, turnover, and age. Finally, a factor analysis was used to find the main way how to improve part-time job offers.

Results: The variety of businesses and different regional locations opens up space for discussion regarding parttime job support. A factor analysis found five significant issues, which could affect local labour market and company behaviour.

Conclusion: The added value of the paper can be seen in the factor identification, where internal willingness to support part-time employment and qualification growth as organizational change must be in first place.
\end{abstract}

Keywords: flexibility; Moravian Silesian Region; part-time employment; SME

\section{Introduction}

Flexibility in the labour market concerns the management of different items such as production, organizational processes, number of working hours and different types of employment. There is a fundamental shift away from factors of material prosperity in favour of intangible assets such as knowledge, invention, innovation and creativity (Čemerková et al., 2016, p. 113), which brings opportunities for employees, but on the other hand obstacles for employers. It changes the behaviour of employees, but also the approach of organizations themselves when working with human capital. One type of employment, used particularly in Western European countries in the area of flexible employment, is part-time employment. Willingly assuming part-time employment creates an opportunity for employees to combine family and work life or to secure at least some source of income in cases when a full-time job is not available. Part-time employment represents an opportunity for employers to keep specialists in the company and to cope with fluctuations in demand (Formánková, et al., 2011).

Received: June 18, 2017; revised: December 2, 2017; accepted: January 5, 2018 
The behavioural change in companies brings about a different ratio between standard forms of employment (8hour working day, 5 working days a week, permanent employment) and non-standard forms of employment. These non-standard forms need to be re-evaluated in contrast to the current concept of employment of workers. Possibilities regarding the amount of flexibility in the labour market are defined by subcontracts and short-term contracts, which could erode the direct relationship between an employer and an employee. A number of factors influencing labour market changes have triggered the need, which was defined by Dušková (2005) and Keller, (2012):

- an increase in the number of employees in services,

- the risks and uncertainties associated with continual changes,

- new forms of ICT technologies,

- an increase in the number of well-paid jobs and knowledge-based positions,

- an increase in the volume of non-fully-fledged forms of work.

In accordance with this, flexible forms of employment need a particularly sensitive approach from superiors and, above all, in-depth communication (Němcová et al., 2016). However, the styles and methods of executive management directed towards part-time employees are often similar to full-time employees, even though these groups of workers have completely different values, views, principles and attitudes (Clinebell and Clinebell, 2007, Wotruba, 1990). Different managerial practices within these two groups represent a prerequisite for understanding employees' needs in order to increase their satisfaction.

The transition of a qualified permanent employee to part-time employment would be a good solution in cases, when the employee still has a standard relationship to the transformed employment and cannot work on a standard daily basis for a variety of reasons (personal, health, etc.). If the employer does not permit reducing the working time, he may well lose the employee who requires this change. An employee leaving unexpectedly means not only the loss of the capital invested in this person, but also brings about new costs associated with training a new employee for a given position in the company.

On the contrary, the recruiting of part-time workers faces several obstacles. The crucial thing arises from the nature of the matter, where part-time jobs offer lower financial incentives and are usually connected with professions where the high qualification of an employee is not required (Sobaih, 2011b). It is this that causes less interest in this type of employment. In addition the lower hourly wage rate and the worse position of an employee in the case of hourly wage rises are considered to be one of the main factors affecting the increase of part-time work in general (Hora, 2009, Sobaih, 2011b). Another problem is related to the perception of part-time work as a possible benefit, which becomes an argument in negotiating non-financial forms of employee benefits, such as a company car or a laptop (Formánková and Kř́̌žková, 2015, Tilly, 1996).

Another group of obstacles arise from employee education and development. Investments in human capital have a similar importance as investments in tangible assets. In the case of a non-standard working regime (part-time work, home office, etc.), businesses tend to restrict access to the activities paid for by the employer (Sobaih, 2011a, Hirsch, 2005). On the other hand, part-time employees do not have the full range of employee benefits and the same hourly wage rate as core employees (Haipeter, 2013). The potential for career advancement is also restricted (Vohlídalová and Formánková, 2012) for part-time employees. It can be argued that a part-time employee is more productive per hour than a full-time employee, because he or she spends less hours at work during the day and is less exposed to stress (Garneo et al., 2013).

A different approach to part-time employees could be illustrated across selected countries around the world. A part-time employee in the USA or in Australia is defined as an employee who works less than 35 hours per week, while in New Zealand and the United Kingdom it is an employee who works less than 30 hours per week. Extreme values were set in Germany, when part-time employment is defined as working less than 36 hours per week, in contrast France puts the number at 20 hours per week (Bardoel, et al., 2007, Fagan et al., 2014). Similar biases are also faced in Australia where the proportion of part-time employment is relatively high, i.e., about $30 \%$ (OECD, 2018).

There is a significant gap between the countries of Western and Eastern Europe (Epstein, et al., 2014, Muffels, 2014, Fialová, 2017) as illustrated in the EU in the period of 2004-2016 in EU countries (Table 1).

As is shown in the Table above, significant differences exist across EU countries, where the situation during the observed period is mostly unchanged. While the OECD median value is a $16.6 \%$ share, only seven countries are hovering around that value in the appropriate quartile. The leading countries for part-time employment are, using the mode value - Netherlands (37.02 \%), United Kingdom $(23.93 \%)$, Ireland $(23.27 \%)$ and Germany $(21.98 \%)$. Clearly lagging behind are Bulgaria (1.86\%), the Slovak Republic (3.66 \%) and the Czech Republic (3.9\%).

Part-time employment is defined in Section 80 and Section 241 of the Labour Code (Act No. 262/2006 Coll. Labour Code) in the Czech Republic. A part-time employee means an employee, whose normal working time, calculated on a weekly basis or as an average over a certain period of employment but not exceeding one year, is shorter than the normal working time of a comparable fulltime worker (Kučina, 2007, p. 18). The smallest number of hours per week is not stated. According to research by the Confederation of Industry and Transport (Svaz průmyslu a dopravy, 2008), reluctance to introduce part-time work in 
Table 1: Number of Part-time Employees in Selected Countries in the EU (as a percentage share of the total number of employees). Source: OECD (2018)

\begin{tabular}{|c|c|c|c|c|c|c|c|c|c|c|c|c|c|c|c|}
\hline Country & 2004 & 2005 & 2006 & 2007 & 2008 & 2009 & 2010 & 2011 & 2012 & 2013 & 2014 & 2015 & 2016 & Median & Quartile \\
\hline Bulgaria & 2.54 & 2.15 & 1.88 & 1.56 & 1.49 & 1.58 & 1.78 & 1.82 & 1.91 & 2.13 & 2.6 & 1.86 & 1.59 & 1.86 & 0 \\
\hline $\begin{array}{c}\text { Slovak } \\
\text { Republic }\end{array}$ & 2.59 & 2.39 & 2.38 & 2.39 & 2.6 & 2.94 & 3.66 & 4 & 3.79 & 4.3 & 4.86 & 5.72 & 5.76 & 3.66 & 25 \\
\hline $\begin{array}{c}\text { Czech } \\
\text { Republic }\end{array}$ & 3.8 & 3.27 & 3.32 & 3.49 & 3.47 & 3.89 & 4.32 & 3.9 & 4.34 & 4.9 & 4.76 & 4.68 & 4.95 & 3.9 & 25 \\
\hline Hungary & 3.58 & 3.57 & 2.95 & 3.7 & 3.37 & 3.84 & 3.99 & 5.21 & 5.15 & 4.9 & 4.5 & 4.38 & 3.96 & 3.96 & 25 \\
\hline Romania & 5.16 & 4.64 & 4.9 & 4.18 & 3.99 & 4.25 & 4.75 & 3.9 & 4.12 & 4.23 & 3.81 & 4.16 & 3.53 & 4.18 & 25 \\
\hline Croatia & 5.74 & 6.79 & 7.3 & 6.1 & 5.75 & 5.95 & 6.39 & 6.65 & 5.26 & 4.83 & 4.77 & 5.64 & 4.72 & 5.75 & 25 \\
\hline Lithuania & 8.64 & 7.54 & 6.52 & 6.5 & 4.57 & 5.58 & 6.53 & 7.56 & 7.88 & 7.25 & 7.24 & 6.75 & 6.95 & 6.95 & 25 \\
\hline Latvia & 8.22 & 6.74 & 5.32 & 5.37 & 6.2 & 7.36 & 8.17 & 8 & 8.34 & 7.65 & 6.56 & 6.84 & 7.31 & 7.31 & 25 \\
\hline Cyprus & 7.34 & 7.38 & 6.8 & 6.49 & 6.81 & 7.44 & 7.92 & 8.67 & 8.95 & 9.97 & 10.95 & 10.59 & 11.9 & 7.92 & 25 \\
\hline Slovenia & 7.53 & 7.39 & 7.8 & 7.83 & 7.5 & 8.33 & 9.45 & 8.61 & 7.93 & 8.58 & 9.59 & 9.16 & 7.96 & 7.96 & 25 \\
\hline Estonia & 7.15 & 6.87 & 6.77 & 6.81 & 6.28 & 8.49 & 8.82 & 8.95 & 8.24 & 8.3 & 7.62 & 8.55 & 8.66 & 8.24 & 25 \\
\hline Poland & 12.4 & 11.72 & 10.85 & 10.7 & 9.25 & 8.66 & 8.72 & 8.32 & 8.5 & 7.72 & 7.1 & 6.41 & 5.95 & 8.66 & 25 \\
\hline Greece & 5.9 & 6.38 & 7.43 & 7.69 & 7.93 & 8.5 & 8.91 & 9.9 & 9.79 & 10.33 & 11.15 & \begin{tabular}{|l|}
11.12 \\
\end{tabular} & 10.96 & 8.91 & 25 \\
\hline Portugal & 9.77 & 9.58 & 9.45 & 10.4 & 9.93 & 9.8 & 9.57 & 11.7 & 12.47 & 11.99 & 10.97 & \begin{tabular}{|l|}
10.53 \\
\end{tabular} & 9.12 & 9.93 & 25 \\
\hline Malta & 8.84 & 9.4 & 8.8 & 9.33 & 9.26 & 9.55 & 10.52 & 11.43 & 11.4 & 11.85 & 12.98 & \begin{tabular}{|l|}
11.95 \\
\end{tabular} & 10.15 & 10.15 & 50 \\
\hline Spain & 8.29 & 10.8 & 10.68 & 10.53 & 10.89 & 11.63 & 12.16 & 12.66 & 13.57 & 14.73 & 14.71 & 14.47 & 14.13 & 12.16 & 50 \\
\hline Finland & 11.31 & 11.2 & 11.41 & 11.71 & 11.5 & 12.24 & 12.48 & 12.7 & 12.98 & 13.4 & 13.32 & 13.4 & 14.1 & 12.48 & 50 \\
\hline France & 13.27 & 13.19 & 13.21 & 13.28 & 13.3 & 13.46 & 13.68 & 13.66 & 13.87 & 14.2 & 14.31 & 14.36 & \begin{tabular}{|l|}
14.22 \\
\end{tabular} & 13.66 & 50 \\
\hline Sweden & 14.43 & 13.53 & 13.43 & 14.36 & \begin{tabular}{|l|}
14.37 \\
\end{tabular} & 14.65 & 14.5 & 14.31 & 14.26 & 14.29 & 14.22 & \begin{tabular}{|l|}
14.14 \\
\end{tabular} & 13.8 & 14.29 & 50 \\
\hline Luxembourg & 13.22 & 13.87 & 12.66 & 13.9 & 13.4 & 16.43 & 15.78 & 16.1 & 15.45 & 15.26 & 15.47 & 14.92 & \begin{tabular}{|l|}
13.58 \\
\end{tabular} & 14.92 & 50 \\
\hline Italy & \begin{tabular}{|l|}
14.78 \\
\end{tabular} & 14.66 & 15.3 & 15.27 & 15.96 & 15.89 & 16.37 & 16.66 & 17.78 & 18.52 & 18.82 & 18.65 & 18.62 & 16.37 & 50 \\
\hline OECD - Total & \begin{tabular}{|l|}
14.97 \\
\end{tabular} & 15.17 & \begin{tabular}{|l|}
15.22 \\
\end{tabular} & 15.43 & \begin{tabular}{|l|}
15.63 \\
\end{tabular} & \begin{tabular}{|l|}
16.46 \\
\end{tabular} & 16.6 & 16.82 & 16.83 & 17.4 & 16.94 & 16.76 & 16.7 & 16.6 & 50 \\
\hline Belgium & 18.54 & 18.52 & \begin{tabular}{|l|}
18.66 \\
\end{tabular} & 18.8 & 18.32 & \begin{tabular}{|l|}
18.24 \\
\end{tabular} & 18.32 & 18.79 & 18.67 & 18.21 & 18.13 & 18.15 & \begin{tabular}{|l|}
17.77 \\
\end{tabular} & 18.32 & 50 \\
\hline Denmark & 17.5 & 17.35 & \begin{tabular}{|l|}
17.87 \\
\end{tabular} & 17.27 & 17.82 & 18.78 & \begin{tabular}{|l|}
19.15 \\
\end{tabular} & 19.2 & 19.38 & 19.2 & 19.7 & 20.3 & 21.72 & 19.15 & 75 \\
\hline Austria & 15.33 & 16.43 & \begin{tabular}{|l|}
16.96 \\
\end{tabular} & 17.35 & \begin{tabular}{|l|}
17.84 \\
\end{tabular} & \begin{tabular}{|l|}
18.69 \\
\end{tabular} & \begin{tabular}{|l|}
19.17 \\
\end{tabular} & 19.2 & 19.44 & 19.86 & 20.94 & 21.3 & 20.89 & 19.17 & 75 \\
\hline Germany & 20.1 & 21.46 & 21.84 & 21.98 & 21.78 & 21.86 & 21.84 & 22.27 & 22.24 & 22.57 & 22.33 & 22.4 & 22.8 & 21.98 & 75 \\
\hline Ireland & \begin{tabular}{|l|}
18.87 \\
\end{tabular} & 19.33 & 19.32 & 19.9 & 20.9 & 23.81 & 24.86 & 25.68 & 25.2 & 24.23 & 23.41 & 23.27 & 22.75 & 23.27 & 75 \\
\hline $\begin{array}{c}\text { United } \\
\text { Kingdom }\end{array}$ & 23.41 & 22.93 & 23.9 & 22.88 & 22.96 & 23.93 & 24.63 & 24.67 & 24.97 & 24.64 & 24.1 & 23.97 & 23.81 & 23.93 & 75 \\
\hline Netherlands & 35.04 & 35.57 & 35.36 & 35.92 & 36.06 & 36.67 & 37.15 & 37.02 & 37.62 & 38.55 & 38.31 & 38.52 & 37.7 & 37.02 & 100 \\
\hline
\end{tabular}

the Czech Republic is caused by managers believing that flexible working hours could lead to insufficient control of working time. Access to the diversity of employees and the use of their potential have an impact on the competitiveness of the enterprise (Němcová et al., 2016), which, in the context of aggregate economic indicators, will be reflected in the performance of the whole region (Mikhaylova, 2016). This problem is closely connected with flexicurity. Flexicurity is a new way of looking at flexibility and security in the labour market, which has been endorsed by EU leaders and the European Commission as a way of solving the Union's employment problems (Černá, 2010, p. 49).

The main goal of this paper is to express the current situation in the labour market on a regional level in order to find out the key factors, which cause a low level of flexicurity among the labour force. According to a study by Couprie and Joutard (2017), who examined the impact of part-time employees during the great recession in France in relationship to the business cycle and Fialová (2017), who dedicated her research to the Central European labour 
market and Fagan et al. (2013), who examined obstacles to part-time employment, it is therefore clear that such connections exist between the regions and ratios of part-time jobs.

Hence, it could conceivably be hypothesised that the trend would be observed in the Czech Republic and regional differences might be significant for evaluation as Urminský (2017) confirmed by its cluster analysis of the labour market. Results of primary research will provide further support for the inductive quantitative hypotheses that were set out according to the previous literature review:

When labour market has an specific behaviour according regional differences (Uminský 2017, Němcová et al., 2016 and Fialová 2017), it is necessary to examine dependence of the labour market structure by its decomposition into several relatively similar subsets, when the branch of the business would play significant role in that relationship (Fejfarová, 2016). We expect that business structure and its economical indicators in examined region could play the role in part time employment so we had formulated following hypotheses:

- Hypothesis 1 (H1): "The branch of business in examined region increases an offer of part-time employment."

- Hypothesis 2 (H1): "The company size exhibits an offer of part-time employment."

- Hypothesis 3 (H1): "The turnover volume brings an extension of offer of part-time employment in SMEs."

\section{Methods}

Primary quantitative research between SMEs was used to obtain relevant data. The theoretical background for the questionnaire structure was based on the VRIO (Barney, 1997) model, particularly for the evaluation of internal competitive advantage in the area of human resources. This approach was combined with the model of business flexibility, published by Slávik and Romanová (2005), followed up by the previous studies of Šebestová (2007) and Pawliczek et al., 2011 and Tvrdoň et al, 2015).

The questionnaire was used to collect data in a rather broad study (business environment, strategy and human resources) and in this paper we will focus on just one aspect of the study - flexibility of work places and part-time job offers in small and medium sized businesses. These businesses must fulfil the criteria of size and turnover according to EU requirements for classification of SMEs ${ }^{1}$. The respondents who fell within this definition of SMEs were business owners or managers, who agreed to a per- sonal visit. SPSS statistical software was used for statistical analysis. The minimum sample size $n$ was calculated by using the formula (Olaru et al., 2010):

$$
n=\frac{t^{2} \cdot p \cdot(1-p)}{\omega^{2}}(1)
$$

where:

t....confidence level, corresponding to the probability with which the accuracy of the results will be guaranteed, from the statistical tables of the student distribution; p....prevalence, probability or proportion of the sample components that will explore the problem; $\omega$....acceptable margin of error.

The questionnaire survey was conducted with owners and managers of small and medium sized businesses (fewer than 250 employees) in the Moravian-Silesian Region (NUTS II), operating between 2009-2013. The companies fulfilled the criteria of being designated as small and medium sized businesses with their number of employees - fewer than 250, operating a business in the area of the Moravian-Silesian Region and agreeing to a personal visit during autumn 2014. Data obtained from questionnaires was analysed through the SPSS statistical packet programme. Research was conducted in order to determine:

- Identification of factors determining business behaviour in the examined region (part A, 10 questions).

- Finding the interaction between the sector according to the type of business and employee structure (part $\mathrm{B}, 16$ questions).

The results were confirmed through the assessment of scale reliability, construct validation and un-dimensionality of the research constructs. Cronbach's Alpha was used to assess the scale reliability of each construct in the research model. The alpha of every factor was greater than the suggested threshold value of acceptable reliability of 0.6. All survey questions utilised a 5-point Likert scale (1 the best, 5 - the worst for non-numerical data).

Minimum Sample Size. Using equation (1), where the $t$ value (sig. $\alpha=0.05$ ) was 1.645 and $\omega=0.05$ was the acceptable error limit of $5 \%$. A prevalence value ( $p$-value) was counted as the proportion of businesses, which were active in 2014 in the MSR (250,028 entities) to the total number of businesses in the Czech Republic (1,470, 929 entities), the p-value was 0.1699 ; then the minimum sample size was counted up to 153 respondents (Tvrdoň et al., 2015). A total of 285 questionnaires were taken from 400 contacted enterprises. Unfortunately, 70 individuals were excluded from the study on the basis of missing data, illogical answers, and contradictory responses. A statistical

1 A SME entrepreneur is considered to be an entrepreneur who employs fewer than 250 employees and whose annual turnover does not exceed EUR 50 million or has an annual balance sheet total which does not exceed EUR 43 million (Recommendation 2003/361/EC) 
evaluation was made for 215 valid responses, whereby the minimum sample size was respected.

The total internal reliability was measured using Cronbach's alpha, which had a value of 0.845 , while the partial analyses internal reliability of data ranged around the value of 0.79 , which satisfies the condition for further data analysis (Nunally, 1978).

To test basic statistical ties, variable methods were used. Cramer's contingency coefficient V, which represents the most appropriate measure of association between two nominal variables was one of the most important. Scale, introduced by Cohen (1988) for the correlation coefficient was used for coefficient interpretation. For predictive interpretation, the formulation that can be found in the work of Liebetrau (1989) was used, where the degree of significance between 0.25 and 0.5 means a factor in the causal linkage and the value between 0.7 and 0.9 makes it possible to predict the factor behaviour in the next period.

\section{Analyses and Results}

The Moravian-Silesian Region is one of 14 regions in the Czech Republic. It is located in the northeast of the Czech Republic and is one of its most peripheral parts. In the north and east it borders with Poland and in the southeast with Slovakia ${ }^{2}$. The cross-border character of this region provides opportunities for effective cooperation in the sphere of production, infrastructure development, environmental protection, cultural and educational activities and in the field of tourism. According to the European regional classification, the MSR is simultaneously classified as NUTS II and NUTS III (Čemerková et al., 2016)³.

Since the $19^{\text {th }}$ century, the MSR has ranked among the most important industrial regions of Central Europe. Its industry is concentrated in the Ostrava-Karvina industrial and mining basin. The MSR has 1,220,000 inhabitants and is the third most populous region in the Czech Republic. However, the MSR is one of the regions with the fewest municipalities. If we take the population in 1995 as a starting index of 100, then the population in 2012 only amounted to an index number of 94.5 . The population decline is caused by the low birth rate since 1993 and, unlike the rest of the Czech Republic, also by migration. Despite the current slow-down of heavy industry and mining, more than a third of the total of 549.1 thousand persons is employed in the Czech economy with another $12 \%$ in trade and repairs of goods. (CSO 2015, MSK, 2017)
The Moravian-Silesian Region has been a region facing a number of problems for a long time. Within the Czech Republic, it is a region with a high unemployment rate. This is mainly structural unemployment because of the decline in the former coal mining and heavy industry. Total gross domestic product (GDP) has always been higher than the national average. However, if we focus our attention on GDP per capita, we can see that the strong position of the MSR disappears. The Moravian-Silesian Region, as the fourth largest regional economy according to a RIM Plus study (Čadil, 2014), generated $10.2 \%$ of the national GDP, and reached $97 \%$ of the national average of GDP in PPS per the employed, the second highest value in the Czech Republic. Despite the modernisation of many companies, the innovation activities in the business sector are rather below average. The Moravian-Silesian Region is traditionally considered a problematic region, in the past it underwent fairly major structural changes, which brought with them a higher unemployment rate and a higher proportion of long-term unemployment, compared with other Czech regions (Adámek et al., 2015). Since 2009, the number of newly formed businesses has continuously decreased, while the number of non-operational entities has grown. This problem in combination with the unsuitable qualification structure of the workforce illustrates the problems in the functioning of the labour market in the MSR as mentioned in Table 2, where regional value added (in comparison with the year 2007) significantly decreases. SMEs in the Czech Republic represent an important group of employers and therefore they need to be taken into account (Fejfarová and Urbancová, 2016, p.86). As a baseline for macroeconomic indicators we chose the year 2007 to be able to evaluate the full supporting period from EU funds (2007-2013) and their impact on the regional competitiveness of the region, specifically focused on human resources development and the adaptability of businesses, where the following formula (2) was used.

$$
\text { Index }_{2007 / 2014}=\text { Indicator }_{2014}-\text { Indicator }_{2007} / \text { Indicator }_{2007} * 100[\%](2)
$$

The industrial structure of the MSR is currently causing many problems that are particularly associated with a higher proportion of unemployed persons. As seen from Table 2, the most striking result to emerge from the data is that the GVA change index decreased significantly. Many companies with high value added moved their main place of business outside of the region and the remainder are mostly connected with low value added production. The

2 http://www.msk.cz/, http://www.risy.cz/cs/krajske-ris/moravskoslezsky-kraj/verejna-sprava/spravni-cleneni/uzemni-cleneni-mapy/

3 The NUTS classification (Nomenclature of territorial units for statistics) is a hierarchical system for dividing up the economic territory of the EU for the purpose of: (1) The collection, development and harmonisation of European regional statistics, (2) Socio-economic analyses of the regions, where NUTS I: major socio-economic regions, NUTS II: basic regions for the application of regional policies, NUTS III: small regions for specific diagnoses, and (3) Framing of EU regional policies.http://ec.europa.eu/ eurostat/web/nuts 
Table 2: Significant Regional Macroeconomic Indicators 2007-2014. Source: CSO, 2015, author's calculations

\begin{tabular}{|c|c|}
\hline Indicators & Index 2007/2014 \\
\hline GDP growth & $8.5 \%$ \\
\hline Growth rate of regional gross value added (GVA) & $-141.9 \%$ \\
\hline Employment rate & $2.1 \%$ \\
\hline Unemployment rate & $1.2 \%$ \\
\hline Migration rate change & $-280 \%$ \\
\hline Population growth & $-2.6 \%$ \\
\hline Business units & $-69.1 \%$ \\
\hline Wages and Salaries & $4.0 \%$ \\
\hline
\end{tabular}

Table 3: Data Sample Description: Business Age. Source: own research

\begin{tabular}{|c|c|}
\hline Age group (years) & Percentage share in the sample \\
\hline $3-5$ & $10.7 \%$ \\
\hline $6-10$ & $18.1 \%$ \\
\hline $11-15$ & $22.3 \%$ \\
\hline $16-20$ & $21.4 \%$ \\
\hline $21-25$ & $24.2 \%$ \\
\hline $26-30$ & $0.9 \%$ \\
\hline More than 30 years & $2.3 \%$ \\
\hline Median (year) & 1999 \\
\hline Percentiles (year) & \\
25 & 1993 \\
50 & 1999 \\
75 & 2005 \\
\hline
\end{tabular}

results are rather surprising in the area of migration, where the ratio is negative it brings a positive effect - the migration rate was lower in 2014 than in 2007. Today, the MSR is the region with the second highest recorded unemployment rate in the Czech Republic. A very significant problem is the proportion of long-term unemployed (over 12 months) in the total number of unemployed, which in the MSR is above the national average. This situation is also reflected in the number of applicants per job vacancy (Čemerková, 2016).

\subsection{Data Sample Evaluation}

The data was collected throughout the whole of the Moravian-Silesian Region; the percentage of respondents in each district corresponds to the percentage proportion of economically active enterprises in this region, where companies with up to 9 employees dominate in the sample ( $46.05 \%$ ), followed by companies with 10 to 49 employees $(27.44 \%)$. On the other hand, companies without employees have a share of $(11.63 \%)$ and companies with 50 to
249 employees made up the rest of the sample (14.88\%). Most of the companies were in a growth $(49.77 \%)$ and mature $(31.63 \%)$ phase of business, in contrast to established companies (15.81\%). A minority of participants $(0.93 \%)$ showed that they plan to wind up their business or are in a state of decline $(1.86 \%)$.

In terms of legal form, the sample can be classified as follows: limited liability companies (45.6\%) and self-employed persons (39.5\%) make up the largest share, joint stock companies are in third place (12.1\%). Other types of enterprises (public companies, non-profit organisations) are present only in small numbers (up to $1 \%$ ). Other qualitative indicators, such as age and branch of business are summarized in Tables 3 and 4.

In the sample we can find both new companies (in existence up to 5 years) and enterprises that operated in the market even before the change of political regime in 1989. The enterprises created in the nineties (after 1990) are the predominant group, where $1 / 4$ of the companies were established before 1993 .

The specialization of SMEs reflects regional macroeconomic profiles, where GVA significantly decreased (see Table 2). 
Table 4: Structure of Company Specialization. Source: own research

\begin{tabular}{|c|c|}
\hline Area of business & Percentage share \\
\hline Agriculture & $1.86 \%$ \\
\hline Industry & $10.70 \%$ \\
\hline Construction & $13.95 \%$ \\
\hline Public services & $3.26 \%$ \\
\hline Trade & $36.28 \%$ \\
\hline Services & $33.95 \%$ \\
\hline Total & $\mathbf{1 0 0} \%$ \\
\hline
\end{tabular}

Table 5: Part-time Employment vs. Branch of Business. Source: own research

\begin{tabular}{|c|c|c|c|c|c|}
\hline \multirow{3}{*}{ Area of business } & \multicolumn{4}{|c|}{ Part-time employment offer } & \multirow{3}{*}{ Total in business group } \\
\hline & \multicolumn{2}{|c|}{ No } & \multicolumn{2}{|c|}{ Yes } & \\
\hline & abs. & $\%$ & abs. & $\%$ & \\
\hline Trade & 50 & $61.73 \%$ & 31 & $38.27 \%$ & 81 \\
\hline Industry & 10 & $40.00 \%$ & 15 & $60.00 \%$ & 25 \\
\hline Services & 47 & $70.15 \%$ & 20 & $29.85 \%$ & 67 \\
\hline Construction & 16 & $55.17 \%$ & 13 & $44.83 \%$ & 29 \\
\hline Public services & 6 & $66.67 \%$ & 3 & $33.33 \%$ & 9 \\
\hline Agriculture & 3 & $75.00 \%$ & 1 & $25.00 \%$ & 4 \\
\hline Total & 132 & $61.40 \%$ & 83 & $38.60 \%$ & 215 \\
\hline
\end{tabular}

\subsection{Part-time Job Offers on a Regional Level}

The present study was designed to determine the effect of part-time job offers regarding other quantitative indicators. The first part of the analysis examines the percentage share of businesses supporting part-time jobs and these results are inputs for multidimensional analysis (based on the Cramer V coefficient for nominal values), where all factors, have an influence on the decision to change personnel policy in small businesses. Factor analysis presents the last part in finding the main factors, which could support or weaken the decision to create part-time jobs.

As is shown in the following Table 5, only 83 companies of the total number of 215 companies $(38.6 \%$ of respondents) answered the question of whether they have part-time workers positively. On the other hand, $61.4 \%$ of respondents (132 enterprises) did not report any part-time work. In our sample, part-time employees formed $29.73 \%$ of the workforce on average.

Part-time employment has a dominant position in industrial enterprises $-60 \%$ of industrial enterprises use this "modern" form of employment. The construction industry occupies second place. Agriculture lies in last place (25\%) when it comes to part-time job offers. Based on the legal form of companies, limited liability companies occupy first place among the companies with part-time employees, where more than half of these companies have parttime workers. Self-employed entities are in second place, with $25 \%$ of their workforce being made up of part-time employees. Joint-stock companies occupy third place, where $38.46 \%$ of these businesses have responded positively to the questions about part-time employees. On the other hand, non-profit organizations and public companies do not have any part-time employees at all. The level of association between part-time employment and company size by number of employees is shown in Table 6 .

To sum up, in terms of size by number of employees, part-time employment accounts for half of the total share - micro-enterprises with $40.4 \%$, small with $44.07 \%$ and medium enterprises $50 \%$. To gain a greater level of association, the relationship between part-time employment and turnover has been described (Table 7; exchange rate EUR $1=\mathrm{CZK} 28$ ).

Part-time employment ranges in the sample from $36.36 \%$ to $66.67 \%$, where the predominant group is made up of companies with a turnover of 35 - 350 thousand EUR per year. To clarify who the "potential" employer is, who prefers to mix part-time jobs with classic employment, we can see that (according to Tables 5-7): "it is an industrial or construction company, in the legal form of a limited lia- 
Table 6: Part-time Employment vs. Number of Employees. Source: own research

\begin{tabular}{|c|c|c|c|c|c|}
\hline \multirow{2}{*}{ Number of employees } & \multicolumn{4}{|c|}{ Part-time employment } & \multirow{2}{*}{ Total in size group } \\
\cline { 2 - 6 } & \multicolumn{2}{|c|}{ No } & \multicolumn{2}{c|}{ Yes } & \\
\cline { 2 - 6 } & abs. & $\%$ & abs. & $\%$ & 25 \\
\hline 0 & 25 & $100.00 \%$ & 0 & $0.00 \%$ & 99 \\
\hline $1-9$ & 59 & $59.60 \%$ & 40 & $40.40 \%$ & 59 \\
\hline $10-49$ & 33 & $55.93 \%$ & 26 & $44.07 \%$ & 32 \\
\hline $50-249$ & 16 & $50.00 \%$ & 16 & $50.00 \%$ & 215 \\
\hline Total & 132 & $61.40 \%$ & 83 & $38.60 \%$ & \\
\hline
\end{tabular}

Table 7: Part-time Employment vs. Turnover (EUR). Source: own research

\begin{tabular}{|c|c|c|c|c|c|}
\hline \multirow{3}{*}{ Turnover (thousand $€$ ) } & \multicolumn{4}{|c|}{ Part-time employment } & \multirow{3}{*}{ Total } \\
\hline & \multicolumn{2}{|c|}{ No } & \multicolumn{2}{|c|}{ Yes } & \\
\hline & abs. & $\%$ & abs. & $\%$ & \\
\hline$<35$ & 35 & $63.64 \%$ & 20 & $36.36 \%$ & 55 \\
\hline $35-350$ & 47 & $62.67 \%$ & 28 & $37.33 \%$ & 75 \\
\hline $350-3500$ & 37 & $61.67 \%$ & 23 & $38.33 \%$ & 60 \\
\hline $3500-9000$ & 6 & $50.00 \%$ & 6 & $50.00 \%$ & 12 \\
\hline $9000-35000$ & 6 & $60.00 \%$ & 4 & $40.00 \%$ & 10 \\
\hline$>35000$ & 1 & $33.33 \%$ & 2 & $66.67 \%$ & 3 \\
\hline Total & 132 & $61.40 \%$ & 83 & $38.60 \%$ & 215 \\
\hline
\end{tabular}

bility company, it has between 50 to 249 employees in total and a turnover of 35 - 350 thousand EUR per year."

We will now turn to the hypotheses formulated in the introduction part of the paper, where H1 stated that: "“The branch of business in examined region increases an offer of part-time employment." . Unfortunately, Cramer's contingency test does not support the significant relation between the use of part-time jobs and the branch of business at the significance level $\mathrm{a}=0.05$ (Cramer's V $=0.192$, Sig. 0.162), therefore the $\mathrm{H} 1$ hypothesis must be rejected. These findings were supported by the cross tab analysis made in Table 5, where only two of the six branches have a significant share of part-time employment, these being construction and industry.

Following on in that manner, hypothesis H2 was formulated as: "The company size exhibits an offer of parttime employment.)." This hypothesis (H2) must be accepted when the relationship between part-time employment and company size by number of employees in SMEs (explored by size group, Table 6) was confirmed at the significance level $a=0.05$ (Cramer's V=0.266, Sig. 0.002). This relationship is statistically significant, although the power of the "tie" between variables is rather small because of the existence of two significant groups in the sample (1-9 employees and 10 to 49 employees). Finally, hypothesis H3 was formulated as: "The turnover volume brings an extension of offer of part-time employment in " (Table 7). This hypothesis (H3) must be rejected, because it did not find any significant relation between the use of part-time employment and turnover at the significance level $\mathrm{a}=0.05$ (Cramer's V $=0.092$, Sig. 0.872). There is a dominating group of 60 enterprises with a turnover of 35 - 350 thousand EUR which plays a significant role in the sample. Taken together, these results suggest that there would be an association between other qualitative variables, which were included in the questionnaire. The next part, therefore, moves on to discuss the possibility of modelling other relationships between questionnaire variables, such as motivation to start up, labour force problems or other strategic issues.

\subsection{Other Factors Influencing Part-time Employment on the Regional Level}

To be able to clarify factors, which have an influence on part-time job offers, we used results from the questionnaire (parts A and B) with a multidimensional approach description (dependent on variables from previous parts: turnover, number of employees, age and branch of business; the business stage and business cycle were excluded from the list because there was no existence of a relationship in 
Table 8: General Results of the Questionnaire. Source: own research

\begin{tabular}{|c|c|c|c|}
\hline & Factor & Measure & Result \\
\hline \multicolumn{4}{|c|}{ ENTREPRENEURIAL MOTIVATION } \\
\hline 1 & Main motivation to start-up & Percent. nominal & $\begin{array}{c}\text { Necessity driven } 17.3 \% \\
\text { Opportunity driven } 72.7 \%\end{array}$ \\
\hline \multicolumn{4}{|c|}{ EXTERNAL FACTORS - PROBLEMS OF LABOUR MARKET } \\
\hline 2 & Barrier in lack of qualified employees & Binominal & $\begin{array}{l}\text { Yes }-18.1 \% \\
\text { No }-81.9 \%\end{array}$ \\
\hline 3 & Quality of labour force & Likert scale (median value) & 3.00 \\
\hline 4 & Amount of labour force in selected location & Likert scale (median value) & 2.00 \\
\hline 5 & Available housing for employees & Likert scale (median value) & 3.00 \\
\hline \multicolumn{4}{|c|}{ INTERNAL FACTORS (BASED ON VRIO APPROACH) } \\
\hline 6 & Strategy of development & Binominal & $\begin{array}{l}\text { Yes }-30.7 \% \\
\text { No }-69.3 \%\end{array}$ \\
\hline 7 & Part-time job places & Binominal & $\begin{array}{l}\text { Yes }-38.6 \% \\
\text { No }-61.4 \%\end{array}$ \\
\hline 8 & Share of part time job places & Percent. nominal (median value) & $10 \%$ \\
\hline 9 & Qualification growth & Binominal & $\begin{array}{l}\text { Yes }-32.1 \% \\
\text { No }-67.9 \%\end{array}$ \\
\hline 10 & Financial plan for qualification growth support & Binominal & $\begin{array}{l}\text { Yes }-65.9 \% \\
\text { No }-34.1 \%\end{array}$ \\
\hline 11 & Own resources for qualification growth & Binominal & $\begin{array}{l}\text { Yes }-52.6 \% \\
\text { No }-47.4 \%\end{array}$ \\
\hline 12 & Projects for qualification growth & Binominal & $\begin{array}{l}\text { Yes }-15.3 \% \\
\text { No }-84.7 \%\end{array}$ \\
\hline 13 & Employee participation for qualification growth & Binominal & $\begin{array}{l}\text { Yes }-8.4 \% \\
\text { No }-91.6 \%\end{array}$ \\
\hline 14 & Organizational changes as form of innovation & Binominal & $\begin{array}{l}\text { Yes }-22.3 \% \\
\text { No }-77.7 \%\end{array}$ \\
\hline 15 & Student job places & Binominal & $\begin{array}{l}\text { Yes }-19.5 \% \\
\text { No }-80.5 \%\end{array}$ \\
\hline 16 & Educational project (EU projects) & Binominal & $\begin{array}{l}\text { Yes }-9.3 \% \\
\text { No }-90.7 \%\end{array}$ \\
\hline
\end{tabular}

any indicator). We selected the data relevant to three main areas: (i) Entrepreneurial motivation (1 item), (ii) External factors - Labour market problems (4 items), and (iii) Internal factors (based on the VRIO approach, 11 items). General results were summarized in Table 8.

What is interesting about the data in this Table is that the quality of the labour force in the examined region is ranked as average (factor 3), but investment into human resource development is very weak (factor 9). Surprisingly, the average value of part-time jobs in companies on the regional level is $10 \%$ (in contrast to $3.9 \%$ on the national level, Table 1). To distinguish the relationship between these factors a preliminary cross-tabulation matrix was used. This Table (Table 9) was evaluated by the Cramer $\mathrm{V}$ ratio.
Previous analysis declared the average validity of statistically significant ties between chosen variables (Cramer V near the value of 0.3 ), this could help to find areas, which need to be expanded in future research application:

- Entrepreneurial motivation - only the tie with the branch of business was established. It was significant in the branch of business of respondents.

- External factors - labour market problems - a low, but statistically significant relationship was proved in the indicator of "available housing for employees" in three areas - turnover, number of employees and branch of business. This factor could cause a decline in job demand due to a lack of housing near the place of business of the company, as Czech people are very mindful of the amount of time they spend commuting 
Table 9: Relationship between Chosen Indicators and Four Dependent Variables. Source: own research, when sign" *” means significance level <0.05, sign"\# " means significance level $<0.1$

\begin{tabular}{|c|c|c|c|c|c|c|c|c|c|}
\hline & & \multicolumn{2}{|c|}{ Turnover } & \multicolumn{2}{|c|}{ Number of employees } & \multicolumn{2}{|c|}{ Age } & \multicolumn{2}{|c|}{ Area of Business } \\
\hline & & Cramer & Sig. & Cramer & Sig. & Cramer & Sig. & Cramer & Sig. \\
\hline & \multicolumn{9}{|c|}{ Entrepreneurial Motivation } \\
\hline 1 & $\begin{array}{l}\text { Main mo- } \\
\text { tivation to } \\
\text { Start-up }\end{array}$ & 0.211 & 0.578 & 0.221 & 0.402 & 0.357 & 0.946 & 0.271 & $0.007 *$ \\
\hline & \multicolumn{9}{|c|}{ External factors - problems of Labour market } \\
\hline 2 & $\begin{array}{c}\text { Barrier in lack } \\
\text { of qualified } \\
\text { employees }\end{array}$ & 0.157 & 0.381 & 0.282 & $0.001 *$ & 0.379 & 0.468 & 0.194 & 0.153 \\
\hline 3 & $\begin{array}{l}\text { Quality of } \\
\text { labour force }\end{array}$ & 0.167 & 0.223 & 0.193 & $0.066^{\#}$ & 0.371 & 0.647 & 0.175 & 0.138 \\
\hline 4 & $\begin{array}{l}\text { Amount of } \\
\text { labour force } \\
\text { in selected } \\
\text { location }\end{array}$ & 0.130 & 0.835 & 0.147 & 0.533 & 0.367 & 0.716 & 0.189 & $0.041 *$ \\
\hline 5 & $\begin{array}{l}\text { Available } \\
\text { housing for } \\
\text { employees }\end{array}$ & 0.178 & $\mathbf{0 . 1 0 0 ^ { \# }}$ & 0.216 & $0.012 *$ & 0.383 & 0.426 & 0.179 & $0.095^{\#}$ \\
\hline & \multicolumn{9}{|c|}{ Internal factors (based on VRIO approach) } \\
\hline 6 & $\begin{array}{c}\text { Strategy of } \\
\text { development }\end{array}$ & 0.341 & $0.000 *$ & 0.303 & $0.000 *$ & 0.377 & 0.488 & 0.123 & 0.661 \\
\hline 7 & $\begin{array}{l}\text { Part-time job } \\
\text { places }\end{array}$ & 0.092 & 0.872 & 0.266 & $0.002 *$ & 0.280 & 0.982 & 0.192 & 0.162 \\
\hline 8 & $\begin{array}{c}\text { Share of } \\
\text { part time job } \\
\text { places }\end{array}$ & 0.372 & $0.009 *$ & 0.353 & 0.107 & 0.357 & 0.988 & 0.350 & $0.078^{\#}$ \\
\hline 9 & $\begin{array}{l}\text { Qualification } \\
\text { growth }\end{array}$ & 0.270 & $0.001 *$ & 0.289 & $0.000 *$ & 0.372 & 0.566 & 0.164 & 0.320 \\
\hline 10 & $\begin{array}{l}\text { Financial plan } \\
\text { for qualifica- } \\
\text { tion growth } \\
\text { support }\end{array}$ & 0.294 & $0.001 *$ & 0.335 & $0.000 *$ & 0.378 & 0.527 & 0.206 & 0.818 \\
\hline 11 & $\begin{array}{c}\text { Own re- } \\
\text { sources for } \\
\text { qualification } \\
\text { growth }\end{array}$ & 0.322 & $0.000 *$ & 0.324 & $0.000 *$ & 0.368 & 0.567 & 0.130 & 0.650 \\
\hline 12 & $\begin{array}{l}\text { Projects for } \\
\text { qualification } \\
\text { growth }\end{array}$ & 0.372 & $0.000 *$ & 0.317 & $0.000 *$ & 0.368 & 0.567 & 0.221 & $0.063^{\#}$ \\
\hline 13 & $\begin{array}{c}\text { Employee } \\
\text { participation } \\
\text { for qualifica- } \\
\text { tion growth }\end{array}$ & 0.124 & 0.655 & 0.119 & 0.388 & 0.428 & 0.145 & 0.092 & 0.874 \\
\hline 14 & $\begin{array}{l}\text { Organization- } \\
\text { al changes } \\
\text { as form of } \\
\text { innovation }\end{array}$ & 0.159 & 0.368 & 0.259 & $0.002 *$ & 0.470 & $0.030^{*}$ & 0.149 & 0.442 \\
\hline
\end{tabular}


Table 9: Relationship between Chosen Indicators and Four Dependent Variables. Source: own research, when sign" *” means significance level <0.05, sign”\#" means significance level $<0.1$ (continued)

\begin{tabular}{|c|c|c|c|c|c|c|c|c|c|}
\hline & & \multicolumn{2}{|c|}{ Turnover } & \multicolumn{2}{c|}{ Number of employees } & \multicolumn{2}{|c|}{ Age } & \multicolumn{2}{|c|}{ Area of Business } \\
\cline { 3 - 9 } & Cramer & Sig. & Cramer & Sig. & Cramer & Sig. & Cramer & Sig. \\
\hline 15 & $\begin{array}{c}\text { Student job } \\
\text { places }\end{array}$ & 0.230 & $\mathbf{0 . 0 4 0 *}$ & 0.234 & $\mathbf{0 . 0 0 8 *}$ & 0.362 & $\mathbf{0 . 0 6 2 ^ { \# }}$ & 0.161 & 0.352 \\
\hline 16 & $\begin{array}{c}\text { Educational } \\
\text { project (EU } \\
\text { projects) }\end{array}$ & 0.138 & 0.533 & 0.180 & $\mathbf{0 . 0 7 2}^{\#}$ & 0.357 & 0.650 & 0.189 & 0.173 \\
\hline
\end{tabular}

Table 10: Rotated Component Matrix. Source: own research

\begin{tabular}{|c|c|c|c|c|c|}
\hline & \multicolumn{5}{|c|}{ Factor } \\
\hline & $\begin{array}{l}\text { Internal } \\
\text { strategy }\end{array}$ & Investments & $\begin{array}{l}\text { Local labour } \\
\text { market }\end{array}$ & $\begin{array}{l}\text { Employee } \\
\text { involvement }\end{array}$ & $\begin{array}{l}\text { Business } \\
\text { environment }\end{array}$ \\
\hline & 1 & 2 & 3 & 4 & 5 \\
\hline $\begin{array}{l}\text { Projects for qualification } \\
\text { growth }\end{array}$ & .830 & & & & \\
\hline $\begin{array}{c}\text { Educational project (EU } \\
\text { projects) }\end{array}$ & .769 & & & & \\
\hline Strategy of development & .518 & & & & \\
\hline $\begin{array}{l}\text { Own resources for qualifica- } \\
\text { tion growth }\end{array}$ & & .893 & & & \\
\hline $\begin{array}{c}\text { Amount of labour force in } \\
\text { selected location }\end{array}$ & & & .789 & & \\
\hline Quality of labour force & & & .736 & & \\
\hline $\begin{array}{l}\text { Employee participation for } \\
\text { qualification growth }\end{array}$ & & & & .901 & \\
\hline Qualification growth & & & & .579 & \\
\hline Business Cycle & & & & & .870 \\
\hline $\begin{array}{c}\text { Barrier in lack of qualified } \\
\text { employees }\end{array}$ & & & & & -.491 \\
\hline & $\begin{array}{l}\text { raction M } \\
\text { ion Methe }\end{array}$ & $\begin{array}{l}\text { Principal Con } \\
\text { rimax with Ka }\end{array}$ & $\begin{array}{l}\text { onent Analysis } \\
\text { r Normalizatio }\end{array}$ & & \\
\hline & Varimax F & on converged $\mathrm{i}$ & iterations. & & \\
\hline
\end{tabular}

to work, especially people in the MSR, who are classified as "local patriots" (Profesia, 2015).

- Internal factors - medium in strength but statistically significant ties were found in two factors - "projects for qualification growth", where these projects are dependent on turnover, number of employees and branch of business. On the other hand, "student job places" as a potential source of part-time jobs relates to turnover, number of employees and business age.

Finally, a factor analysis was provided, the Kaiser-Meyer-Olkin Measure of Sampling Adequacy (KMO) was 0.629 (Approx. Chi-Square 291.953, Sig. 0.000), where five factors were extracted (variance explained in $65.129 \%$ ), where part-time job offers (in the form of the share of part-time places) were dependent on variables (Table 10).

Two-fifths of factors are from the external environment (factors 3 and 5), contrary to internal factors 1,2 and 4, which have more impact on total variance explained. It explains that current behaviour is influenced by personnel strategy, willingness to change the current situation and willingness to invest in organizational change (in the form of part-time jobs). This model described the current situation in the region and the main forces, which pose obstacles (business environment, local labour market) and on 
the other hand, opportunities, which arise from the internal environment (internal strategy, investments and employee involvement).

\section{Discussion and Conclusion}

Although the literature (Čadil, 2014, Dušková, 2005, Fejfarová, 2016, Fialová, 2017) states that part-time employment is not attractive to enterprises in the Czech Republic - they use it only to a small extent, survey results in the SMEs segment in the NUTS II Moravian-Silesian Region found out that SMEs use them considerably more. A total of $38.6 \%$ of enterprises answered the question of whether they have part-time workers affirmatively. Part-time employees form $29.73 \%$ of the workforce on average according to the survey results.

The survey also showed that all types of businesses use part-time workers; there is no fundamental difference between them. Significant areas were described, such as the area of internal investment into organizational change so as to be able to offer part-time jobs (factor 2, Local labour market - Table 10).

Being flexible is one of the prerequisites for success. This ability is reflected in many aspects. One of them is flexibility in active work with human capital. This flexibility allows the company to work with high-quality employees. These employees play a key role in each company's life, which was confirmed by factor 4 (Employee involvement - Table 10).

Part-time employment is a flexible form of employment. Given the many problems faced by the Moravian-Silesian Region it was found that SMEs consider parttime employment to be very positive. If companies make good use of other forms of flexibility, they have a chance to be successful and contribute to the development of the region.

The presented study highlighted the local impact of entrepreneurship activity and willingness to support parttime jobs, which is also the main limitation of the presented study, when it is connected with the local labour market and the local quality of the labour force, when the effect of migration of the labour force was excluded. Consequently, motivation to invest in human resources must be taken as a starting point for understanding the issue of SMEs innovativeness, especially in the area of organizational innovations. Despite these limitations, the relationships between the type of business and activities leading to part-time jobs growth on the one hand and willingness to cooperate with employees on the other hand show the potential for motivation and support of cooperation.

Moreover, more systematic research and evaluation of part-time job forms is needed, not only on a central level, but on the local level to support bottom-up organizational innovations, not only centralized activities according to regional specialization. The structure of the labour force on the local level affected by an aging population, number of people with disabilities and changes in industry structure on the regional level - these are the challenges for parttime employment support as organizational innovation (Fagan, 2014).

\section{Acknowledgements}

The Ministry of Education, Youth and Sports supported this paper Czech Republic within the Institutional Support for Long-term Development of a Research Organization in 2017, contract Nr. 3201.

\section{Literature}

Adámek, P., Čemerková, Š., Klepek, M., Šebestová, J. \& Šperka, R. (2015). Regional Innovation Approach: A Case of the Moravian-Silesian Region. In Klímová. V. \& V. Žitek. (Eds.), 18th International Colloquium on Regional Sciences, Conference Proceedings (pp. 72-80). Brno: Masarykova univerzita.

Bardoel, A., Morgan, E. L. \& Santos, C. (2007). Quality part-time work in Australian organizations: implications for HRD. Human Resource Development International, 10 (3), 281-299. http://dx.doi. org/10.1080/13678860701515307

Čadil, V. (2014). Regional Innovation Monitor Plus (RIM Plus) - Regional Innovation Report Moravskoslezsko. Technopolis (group).

Čemerková, Š. (2016). Logistics Communication - Important Factor of Successful Business: Case Study for SMEs in Moravian-Silesian Region. In Global Business Conference 2016 Proceedings (pp.48-61). Zagreb: Innovation Institute.

Čemerková. Š., Šebestová, J. \& Stelmach. K. (2016). Nauka o podniku I.[Basics of Business Economics I.] Bratislava: Kartprint.

Černá, L. (2010). Flexibilita a istota na trhu práce. [Flexibility and security factors on the labour market]. In Sborník prìspěvki̊ z VIII. Mezinárodni konference Hospodářská politika v členských zemích Evropské unie (pp. 49-55). Karviná: SU OPF.

Clinebell, S. K. \& Clinebell. J. M. (2007). Differences between part-time and full-time emplyees in the financial service industry. Journal of Leadership and Organizational Studies, 14(2), 157-167.

Cohen, J. (1988). Statistical Power Analysis for the Behavioral Sciences. New York: L. Erlbaum Associates.

Couprie, H., \& Joutard, X. (2017). Atypical Employment and Prospects of the Youth on the Labor Market in a Crisis Context. Cergy-Pontoise: Université de Cergy-Pontoise. (THEMA Working Paper n²017-08).

CSO, (2015). Časové řady za Moravskoslezský kraj. [Moravian Silesian Region in Time series]. Retrieved 
May 28, 2015, from https://www.czso.cz/csu/xt/casove_rady regionalni

Dušková, L. (2005). Vliv změn globálních podmínek na organizaci pracovní doby [An influence of global conditions on working time organization]. Retrieved May 20, 2017 from http://kvalitazivota.vubp.cz/

Epstein, C. F., Seron, C., Oglensky, B., \& Saute. R. (2014). The part-time paradox: Time norms, professional life. Family and Gender. New York: Routledge.

Fagan, C. et al. (2014) In search of good quality part-time employment. Geneva: ILO.

Fejfarová, M. \& Urbancová, H. (2016). Human Resource Management in Small and Medium Sized Enterprises in the Czech Republic. Scientific Papers of the University of Pardubice, Series D, 23 (36), 79-90.

Fialová, K. (2017). Why don’t Eastern Europeans Work Part-time? Ekonomický časopis [Journal of Econom$i c s], 2$ (65), 125-142.

Formánková, L. \& Křŕžková. A. (2015). Flexibility trap the effects of flexible working on the position of female professionals and managers within a corporate environment. Gender in Management: An International Journal, 30(3), 225-238. https://doi.org/10.1108/ GM-03-2014-0027

Formánková, L., Dudová, R. \& Vohlídalová, M. (2011). Bariéry a možnosti využití flexibilnich forem práce v Č́R z komparativni perspektivy. [Barriers and possibilities to use flexible forms of employment in the Czech Republic - A comparative study] Praha: SÚ AV ČR.

Garneo, A., Kampelmann, S. \& Rycx, F. (2013). Part-time Work. Wages and Productivity: Evidence from Belgian Matched Panel Data. Retrieved May 20, 2017 from http://www.ftp.iza.org/dp7789.pdf

Haipeter, T. (2013). Quality Part-Time Work in Germany. International Labor Brief, 11(9), 17-29.

Hirsch, B. T. (2005). Why do part-time workers earn less? The role of worker and job skills. Industrial and Labor Relations Review, 58 (4), 525-551.

Hora, O. (2009). Český trh práce z hlediska vybraných forem flexibility a kvality pracovního života. [Czech labour market from aspect of part time employment and quality of working life] Fórum sociální politiky, 3 (2), 5-13.

Keller, J. (2012). Tři sociální světy. [Three Social worlds]. Praha:SLON.

Kučina. P. (2007). Flexibilní formy práce a jejich právní úprava. [Flexible forms of work and their legal definition]. Praha: VÚ BP.

Liebetrau A. M. (1983). Measures of association. (Quantitative Applications in the Social Sciences Series). Sage Publications. Newbury Park.

Mikhaylova A. A. (2016). The Role of Human Capital in Providing Innovation Security of the Region. Journal of Applies Economic Sciences, 11 (46), 1724-1735.
Muffels. R. J. (2014). Flexibility and employment security in Europe. Cheltenham: Edward Elgar Publishing.

Němcová, I., Marková, H., Polonský, D. \& Malátek, V. (2016). Využití částečných pracovnich úvazků v systému ř́zení lidských zdrojů v Moravskoslezském kraji. [Part time employment in HR management: Case of Moravian-Silesian Region] Karviná: SU OPF.

Nunnally, J. C. (1978). Psychometric Theory. New York: McGraw-Hill.

OECD, (2018). Part-time employment rate (indicator). http://dx.doi.org/10.1787/f2ad596c-en

Olaru, M., Dinu, V., Stoleriu, G., Şandru, D. \& Dincă., V. (2010). Responsible Commercial Activity of SMEs and Specific Values of Sustainable Development in Terms of the European Excellence Model. Amfiteatru Economic, 12 (27), 10-26.

Pawliczek, A., Rylková, Ž., Šebestová, J., Antonová, B., Piszczur, R., \& Veselá, K. (2011). Adaptabilita podnikání v reakci na turbulentni politicko-ekonomické prostředí a technologický pokrok v kontextu udržitelného rozvoje. [Adaptability of Business in political and economical environment in context of sustainability of business, reseach paper]. Výzkumná zpráva katedry managementu a podnikání. Karviná: SU OPF.

Profesia (2015). Lidé jsou nejčastěji ochotni dojiždět do práce 60 minut denně . [People are most willing to commute to work 60 minutes a day]. Retrieved May 20, 2017 from http://www.profesia.cz/cms/newsletter/ duben-2015/lide-jsou-nejcasteji-ochotni-dojizdet-doprace-60-minut-denne/44863.

Šebestová, J. (2007). Analýza faktori̊ ovlivňujicich rozvoj malého a středního podnikání v Moravskoslezském kraji. [Analysis of factors influencing the development of small and medium-sized enterprises in the Moravian-Silesian Region].Karviná: Slezská univerzita v Opavě.

Slávik, Š., \& Romanová, A. (2005). Predvídavost' a pružnost' podnikov. Výsledky prieskumu.[Enterprise foresight and its flexibility. Survey results]. In Nové trendy $v$ podnikovom managemente. Košice: PHF EU Bratislava.

Sobaih, A. E. E. (2011a). Half Job - Half Training? Management Perceptions of Part-time Employee Training in the Hospitality Industry. Journal of Human Resources in Hospitality \& Tourism, 10(4), 400-420. https:// doi.org/10.1080/15332845.2011.588563

Sobaih, A. E. E. (2011b). Success through the part-time employees. A step by step practical toolkit to enhance management practices with part-time employees. Saarbrücken: LAP Lambert.

Svaz průmyslu a dopravy (2008). Flexibilni formy práce aneb jak to vidi zaměstnavatelé. [Flexible forms of work and how employers see it now]. Retrieved May 25, 2017 from http://www.spcr.cz/projekty/real- 
izovane-projekty/2079-zavery-z-konference-flexibilni-formy-prace-aneb-jak-to-vidi-zamestnavatele

Tilly, C. (1996). Half a Job: Bad and Good Part-Time Jobs in a Changing Labour Market. Temple University Press. Philadelphia.

Tvrdoň. M., Šebestová. J., Klepek. M. ,Čemerková. Š., Šperka. R., \& Adámek. P. (2015). Vliv podnikatelského prostředi na udržitelnost podnikáni: príklad Moravskoslezského kraje. [The influence of the business environment on business sustainability: Case of Moravian-Silesian Region] Karviná: SU OPF.

Urminský, J. (2017) Classification of labor markets in the Czech Republic. Forum Scientiae Oeconomia, 5(1), 105-117. http://dx.doi.org/10.23762/fso_vol5no1_9

Vohlídalová, M. \& Formánková. L. (2012). Částečné úvazky v České republice: šance nebo riziko? [Parttime jobs in the Czech Republic: A chance or the risk?] Fórum sociální politiky, 6(5), 17-21.

Wotruba, T. R. (1990). Full-time vs. part-time sales people: A comparison on job satisfaction, performance and turnover in direct selling. International Journal of Research Marketing, 7(2), 97-108.
Šárka Čemerková, Assistant Professor, is an experienced researcher focusing on logistics and business processes. She has taken part in several EU and institutional projects focused on Small business development. Research interests: business economics, logistics, human resources.

Jarmila Šebestová, Associate Professor, is an experienced researcher focusing on Small Businesses. She has participated in a number of international projects, including IPREG (Innovative Policy Research for Economic Growth) and the E-WORLD project (International Entrepreneurs Network). She is Vice President of the European Council of Small Businesses for the Czech Republic. Research interests: small business performance, small business dynamics.

Roman Šperka, Associate Professor and Head of the Business Economics and Management Department at Silesian University in Opava, School of Business Administration in Karvina, Czech Republic. He has participated in several EU and institutional projects. He is Programme Co-Chair of the KES-AMSTA conference. Research interests: business process management, process mining, modelling and simulation of social systems. 